\title{
Understanding the social consumer fashion brand engagement journey: insights about reputed fashion brands
}

\author{
Muhammad Naeem $^{1} \cdot$ Wilson Ozuem ${ }^{1}$
}

Revised: 30 April 2021 / Accepted: 7 May 2021 / Published online: 19 June 2021

(c) The Author(s), under exclusive licence to Springer Nature Limited 2021

\begin{abstract}
The rise of social media platforms (SMPs) has increased information exchange, which can influence social consumer fashion brand engagement (SCFBE). Although there is evidence that SMPs increase online purchasing, there is limited understanding regarding how SMPs affect social fashion engagement, fashion brand relevance, and buying decisions. The present study targeted social media users who directly or indirectly engaged with reputed fashion brands in the UK. Findings revealed that social passion, social tendency, individual warmth, and social liking enhance social fashion brand engagement. The study found that equitable fit, bearability, and viability are three important factors of fashion brand relevance. Finally, social ties and trust, credibility, homophily, and discounts are the drivers of purchasing decisions for fashion brands. Based on the results, the study presents a SCFBE model, which is supported by the triangular theory of love and social impact theory. The results of this study can inform marketing managers within fashion brand organizations of the driving forces of SCFBE.
\end{abstract}

Keywords Social media platforms (SMPs) $\cdot$ Social consumer fashion brand engagement (SCFBE) $\cdot$ Social passion $\cdot$ Brand relevance $\cdot$ Fashion brands

\section{Introduction}

Social media platforms (SMPs) have provided new ways to exchange brand-related information and influence the purchase decision making of customers (Helme-Guizon and Magnoni 2019; Martínez-López et al. 2020), which has increased the importance of SMPs for brands, marketers, businesses, and consumers (Naeem 2020; Simon and Tossan 2018; Martínez-López et al. 2020). Almost half (47.5\%) of 2000 US online fashion shoppers surveyed by Yotpo said that their most recent online fashion purchase was inspired by social media (Retail Wire 2019). According to Arnold (2017), 72\% of Instagram users reported that they bought beauty and fashion brands based on Instagram posts. Furthermore, Arnold (2017) stated that $71 \%$ of social media users accepted peer recommendations for fashion brands.

Muhammad Naeem

dr.muhammadnaeem222@gmail.com

$\checkmark$ Wilson Ozuem

Wilson.ozuem@cumbria.ac.uk

1 University of Gloucestershire, Cheltenham, UK
Prior research highlighted that there is limited understanding of the capability of SMPs to offer opportunities to create socially generated brand passion between customers and fashion brands (Astakhova et al. 2017; Jin and Ryu 2019). Researchers have found that strong brand passion and engagement can create intention to pay a high price, strong word of mouth, brand engagement, and buying intentions (Astakhova et al. 2017; Loureiro et al. 2017; Swimberghe et al. 2014). However, there is limited literature available regarding the factors that can enhance social consumer fashion brand engagement (SCFBE) on SMPs.

There is a strong connection between social media and fashion because both have become part of people's daily lives (Pourazad et al. 2019; Martínez and Tossan 2018). The wearing of fashion brands is a way to present oneself at social events, especially when fashion has become a social passion. People want to express themselves as different through their fashion (Loureiro et al. 2017; Felix and Borges 2014). Some people want to socially influence others through their fashion and style. SMPs are increasingly used as platforms to persuade others to buy certain products and to offer recommendations based on experiences (Morra et al. 2018; Carroll 2009). 
People follow personalities they idolize on social media. Some social media celebrities/influencers have a large fanbase on social media. Followers of social media influencers perceive the influencers to be open minded, artistic, curious, and intelligent (Pourazad et al. 2019). Consumers looking to buy fashion brands often follow fashion experts on social media and take their advice on buying fashion products (Swimberghe et al. 2014; Schivinski and Dabrowski 2016). However, recent studies revealed that people only accept recommendations and influence from socially credible and relevant sources (Naeem 2020; Simon and Tossan 2018; Martínez-López et al. 2020), such as well-known friends and family members, rather than celebrities and fashion experts (Naeem and Ozuem 2020; Simon and Tossan 2018; Martínez-López et al. 2020).

Many studies on SMPs have investigated different perspectives of fashion brands: celebrity endorsement (Jin and Ryu 2019), consumer behavior and brand equity (Loureiro et al. 2017; Godey et al. 2016), visuals and brand familiarity (Buschgens et al. 2020; Lee et al. 2018), purchase intentions (Morra et al. 2018), power of brand passion (Pourazad et al. 2019), brand communications (Carroll 2009), negative effects of marketing (Park et al. 2018), and electronic word-of-mouth engagement (Ananda et al. 2019). However, there is a lack of research on the ways in which social media generates and increases social passion and wisdom of the crowd (socially constructed knowledge) in relation to social fashion engagement, but not necessarily consumer brand engagement. Understanding why some social media posts inspire people to purchase fashion items would be extremely valuable to fashion brands. This article provides a framework that managers can use to quickly identify these "social engagement drivers" and "purchase drivers" based on social media content. This study aims to understand the social and subjective realities of interviewed social media users who purchase fashion brands to investigate three important factors: factors of social fashion engagement; socially constructed determinants of fashion brand relevance; and, specifically, factors that can enhance buying decisions for fashion brands and consumer fashion brand engagement. These factors are helpful to understand SCFBE. The results of this study can enhance understanding about the factors of social engagement, brand relevance, and, most importantly, the determinants of purchasing fashion brands.

\section{Theoretical framework}

Consumers' love for a brand can enhance their level of attachment to a brand, brand passion, positive evaluations of a brand, declarations and sharing of love for a brand, and positive emotions for a brand (Albert et al. 2008). Recent studies revealed that user-generated content on fashion brands on social media can create emotional and social engagement (Algharabat et al. 2020; Cheung et al. 2020; Hollebeek et al. 2014); however, other factors can influence buying decisions for fashion brands. The present study explores: (1) factors that influence social consumer fashion engagement, (2) elements of fashion brand relevance, and (3) factors that can influence buying decisions in relation to fashion brands.

The concept of brand passion is found in research on the psychological perspective of interpersonal relationships (Albert et al. 2008; Carroll and Ahuvia 2006). People engage in interpersonal relationships through social media for some common cause or intentions, such as getting information on fashion brands (Naeem and Ozuem 2020). Sternberg's triangular theory of love highlighted that interpersonal relationships or love are established on the basis of three components: passion, intimacy, and decision/commitment. Passion is the driving force behind the motivation to engage in a social activity. Hatfield and Sprecher (1986) defined passionate love as a state of intense longing for a relationship with another person that manifests through emotions (desire for union, attraction, physiological arousal, and longing for reciprocity), cognitions (idealizing, intrusive thinking, and desire to know the other person), and behavior (determining and maintaining the relationship). These dimensions have been adopted by marketing researchers to argue for the existence of relationships between brands and consumers. Prior research argued that the social exchange of brand-related information through SMPs increased social motivation for brand engagement and brand purchases (Osei-Frimpong and McLean 2018; Osei-Frimpong et al. 2019; Naeem and Ozuem 2020); however, these studies did not reveal the factors that can convert social engagement into purchase decisions and consumer brand engagement. Therefore, this study applied Sternberg's triangular theory of love to fashion brands from a social perspective to understand SCFBE in the context of SMPs.

According to social impact theory, the extent to which people's buying decisions for brands can be influenced by those around them depends on the psychological and physical closeness among the group, and the number of people who share recommendations and experiences (Latané 1981, 1996; Simon et al. 2016). Thus, a group with close proximity, status and credibility would have a significant influence on individual members (Simon et al. 2016). However, a high rate of increase in the number of members of a group decreases the group's influence (Latane and Wolf 1981). According to social impact theory, multiple sources of influence are likely to exert more influence on the consumer than one source of influence. Research showed that a consumer is more likely to believe a message projected from different sources than from a single source (Mir and Zaheer 2012; Slater 2007; Kizgin et al. 2018; Peters et al. 2013). However, 
the perceived credibility of the sources is dependent on three conditions: the arguments in the message must be compelling (Byrum 2019); the media projecting the message must be independent of each other (Narangajavana Kaosiri et al. 2019; Balakrishnan and Griffiths 2017); and sources must be selectively screened for their influence on the consumer.

Muntinga et al. (2011) conducted a study on factors of SMPs that can enhance customer brand engagement and found that the most important factors were remuneration, entertainment, and information. Tsai and Men (2013) reported that several social motivational factors (i.e., entertainment, social integration, remuneration, empowerment, personal identity, and information) enhanced customer engagement with Facebook group pages. Ramirez et al. (2018) found that user-generated content on SMPs was a source of social factors that enhanced word of mouth and customer brand engagement.

Researchers argued that most brand-related literature focused on consumer brand engagement (Osei-Frimpong and McLean 2018; Osei-Frimpong et al. 2019); however, there is little understanding of how people become socially engaged with, and influenced by, fashion brands. There are various social actors on SMPs who can encourage social fashion engagement, such as celebrities, brand-sponsored advertisements, and recommendations from brand users (Naeem and Ozuem 2020; Simon and Tossan 2018; Martínez-López et al. 2020), but not all sources are relevant and credible. There is evidence that some people do not perceive celebrities and brand-sponsored advertisements as credible or relevant (Arnold 2017; Retail Wire 2019; Naeem and Ozuem 2020); therefore, they usually have little impact on purchase decisions. The present study identifies a range of factors that can enhance SCFBE through SMPs.

Previous studies investigated the ways in which consumer brand engagement could be achieved through social media (Algharabat et al. 2020; Cheung et al. 2020; Hollebeek et al. 2014), but these studies focused on either psychological or communication-related factors rather than the social context of SCFBE. Research showed that over a billion social media users made a significant contribution toward changes related to brand engagement and lifestyle of consumers (Algharabat et al. 2020; Cheung et al. 2020; Hollebeek et al. 2014). Some studies on social media and brand engagement did not provide any theoretical support to justify the arguments and results of their study (Algharabat et al. 2020; Jin and Ryu 2019). Other studies applied different theories and models, such as social identity and social exchange theories (Simon et al. 2016), consumer culture theory (Hollebeek et al. 2014), social presence theory (Osei-Frimpong and McLean 2018), and habitus social theory (Buschgens et al. 2020); however, these theories did not provide guidance regarding the socially generated passion and impact of SMPs that can enhance SCFBE. Furthermore, the studies did not reveal what the most credible sources and influencing factors that can influence SCFBE are.

The contribution of social impact theory is the addition of strength and immediacy as variables. These variables have not been included and researched in the context of fashion brands. These variables have attracted operational definitions from researchers due to the complex nature of these variables. The strength of the source is distinguished on the basis of social credibility; a socially credible personality is thought to be more influential than unknown social media users. The immediacy of the source is distinguished on the basis of the physical distance between the source and target; the shorter the distance between the source and the target, the greater the influence of the source on the target. This study culminates in a theoretical framework based on social impact theory and the triangulation theory of love to understand SCFBE in the context of SMPs (see Fig. 1).

\section{Research methodology}

This is the first study to theoretically conceptualize SCFBE using relativist ontology and a social constructionist epistemological approach in the context of fashion retailing in the UK. This study aims at facilitating fashion brand managers in their understanding of social brand engagement. This study explores the social aspect of SCFBE to answer how, who, when, and why social media users generate social fashion engagement and how this social fashion engagement can convert into consumer fashion engagement and buying decisions. This study also explores how social consumption, creation, and exchange on social media generate a social impact on SCFBE (see Fig. 2).

\section{Population and sampling}

The present study targeted social media users based on the following inclusion criteria: they must have one or more social media accounts; they use at least one of the following fashion brands-Tommy, Adidas, Nike, the North Face, or Gucci; they must be $18+$ years of age; and they voluntarily share their knowledge for this study. The study used virtual snowball sampling to identify local friends, friends of friends, and social celebrities in the UK who follow and post information on fashion brands, particularly for Tommy, Adidas, Nike, the North Face, and Gucci on SMPs. The profiles of friends as well as posts of friends of friends (i.e., like, tweet, picture sharing, comment, and video) on social media made it easy to identify the right sample for this study.

These respondents were given the option to attend an interview via telephone, Zoom, Skype, or whatever was convenient for them due to COVID-19 pandemic. The researcher followed ethical guidelines and informed the 


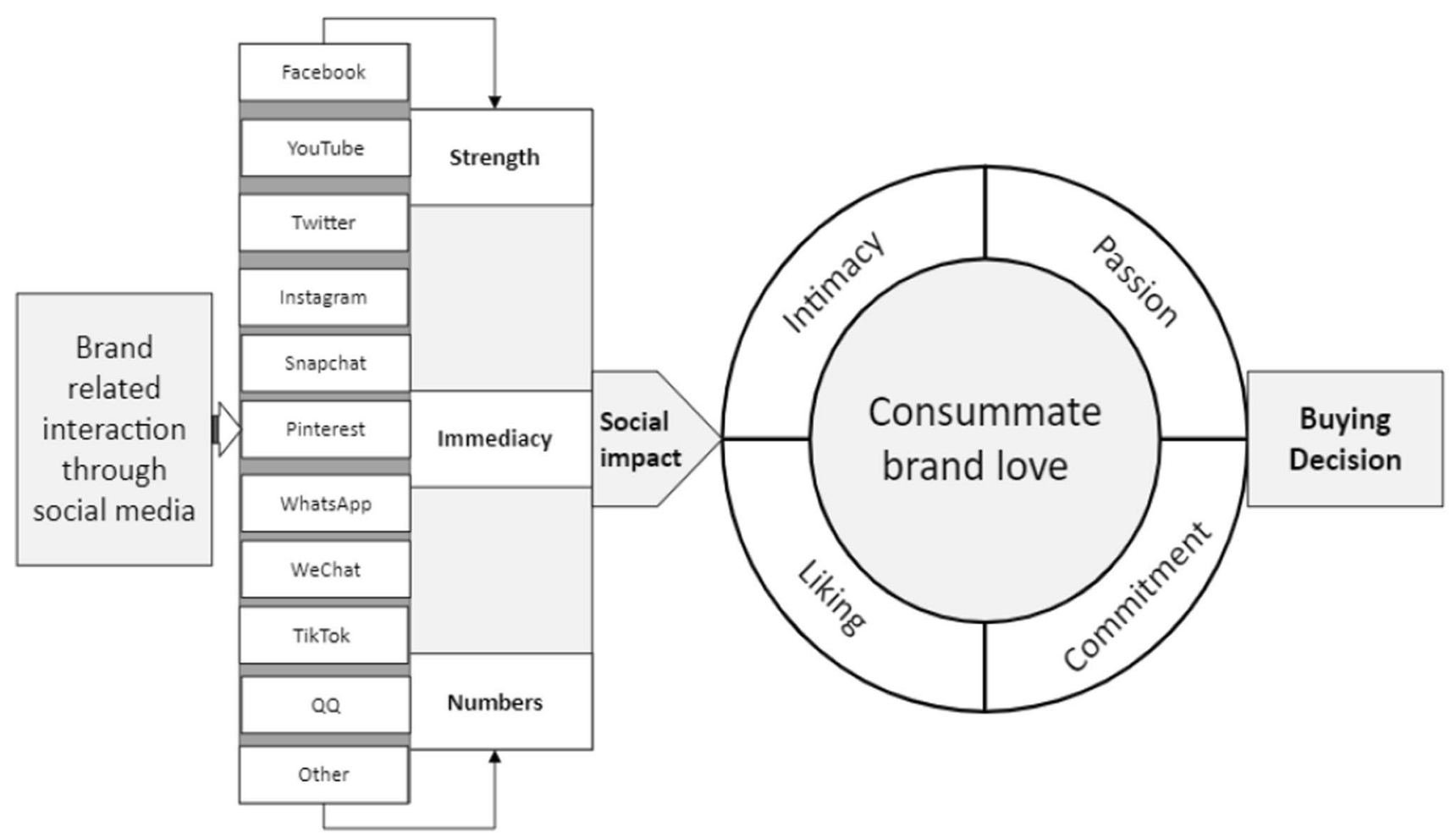

Fig. 1 Theoretical underpinnings

respondents that their contribution was voluntary, and they were free to leave any question or interview session at any stage. Saunders et al. (2018) observed that, on average, 30 participants were chosen for qualitative surveys in different qualitative studies. They observed that this number of participants could be regarded as sufficient to achieve legitimate research. In the present study, the saturation point was achieved at the 32nd interview. In this study, all participants expressed their own views regarding multichannel buying and brand engagement in the context of fashion brands. This study collected data from 32 non-professional and professional individuals, such as fashion experts, professional employees, homemakers, students, parents, self-employed, and business owners who shared their views about fashion brand engagement in the social context (see Table 1). This study selected multiple sources for data collection in order to improve the validity and credibility of the study's findings, as recommended by Aslam et al. (2018). In addition to this, some ethical protocols were followed in this research to increase research quality.

\section{Instrument}

This study conducted semi-structured interviews rather than structured interviews because semi-structured interviews tend to enhance conversation (Adams et al. 2014). Researchers have argued that semi-structured interviews provide more time flexibility to target a few respondents so that the researcher can develop a frank relationship and get richer insights (Adams et al. 2014); therefore, semi-structured interviews are suitable for social constructionists. The average duration of the semi-structured interviews was 25 to $45 \mathrm{~min}$. Interviewees were informed that their interviews would be recorded if they gave their consent; otherwise, the researcher would take notes of important points. Interviewees' body language was also observed constantly during the whole interview process so that their expressions could be converted into meaningful information.

\section{Trustworthiness in the case of qualitative research findings}

Qualitative studies focus on confirmability, credibility, dependability, and transferability to maintain rigorous and trustworthy outcomes. Lincoln and Guba (1982) suggested replacing internal validity with credibility, objectivity with confirmability, reliability with dependability and validity with transferability. In the case of qualitative research findings, transferability can be increased by providing thick descriptions regarding the research process. For example, transferability in the current study is increased by the provision of a detailed justification for the selection of interview method. Dependability can be achieved by clearly documenting the research process and ensuring that it is traceable and logical. In the current study, the researchers critically 


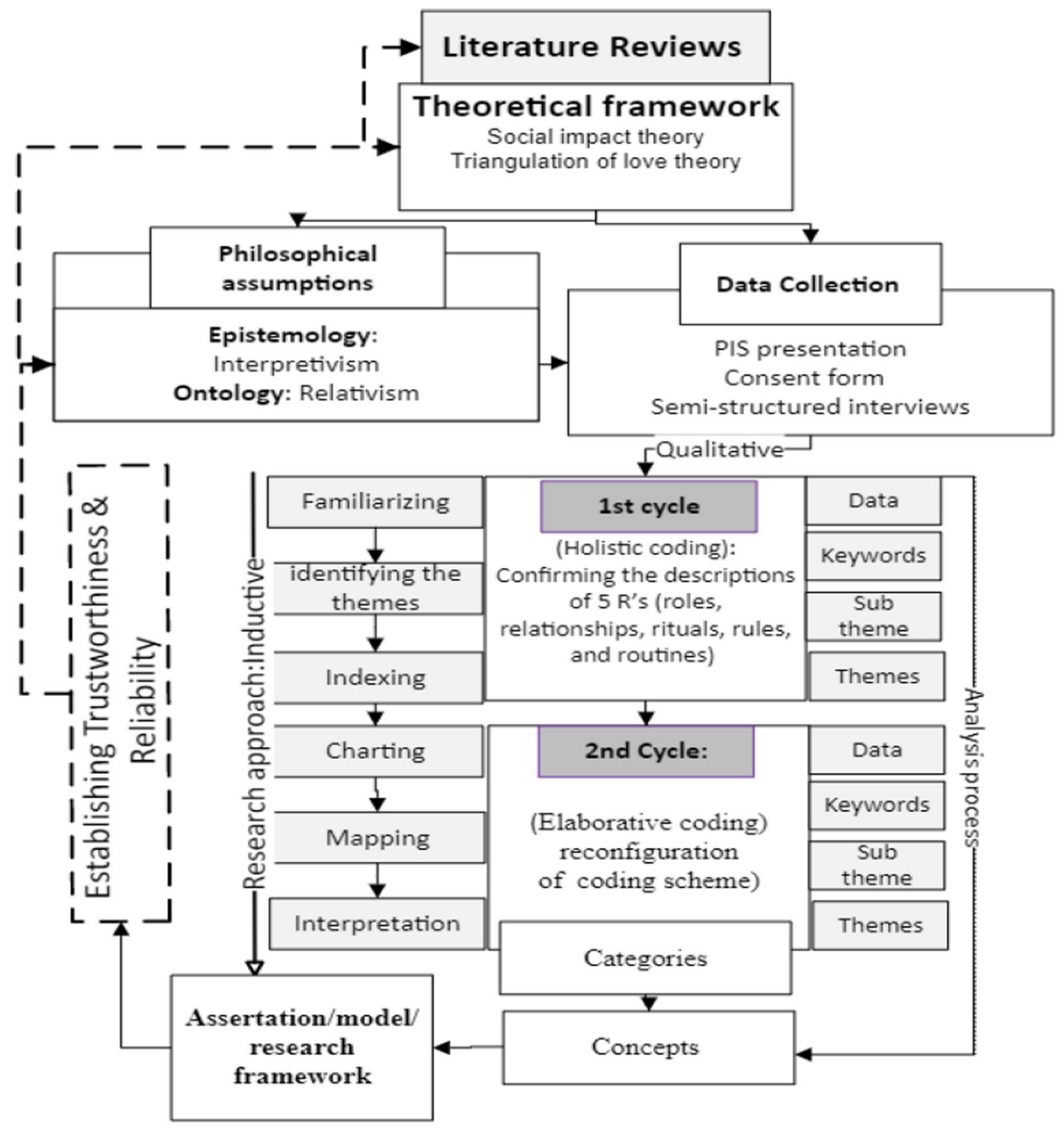

Fig. 2 Research process

analyzed previous studies to determine existing research gap. Typically, confirmability can be ensured only when dependability, credibility, and transferability have already been established (Lincoln and Guba 1982). Researchers can achieve confirmability by fairly presenting the findings and interpretations of their qualitative research, which are usually extracted from data that have been collected. According to Bitsch (2005), it is possible for researchers to evaluate the interpretations and recommendations of qualitative study findings. For example, in this study the researchers evaluated the collected data multiple times in order to ensure the overall trustworthiness of the interpretations and recommendations of their qualitative research findings. Moreover, through the utilization of quotations, this study has made it easy for readers to determine whether the interpretations of collected data are perfectly aligned with quotations given within the findings and analysis section.

\section{Data analysis}

This study used two coding cycles, an audit trail and a reflective diary to ensure rigor and transparency in the research, as suggested by Auerbach and Silverstein (2003) (see Fig. 2 for details). This study used a five-stage data analysis process: identifying the patterns, familiarization with themes, indexing, mapping, and charting. After 
Table 1 Interview participants

\begin{tabular}{|c|c|c|c|c|c|c|}
\hline No. & Age & Gender & $\begin{array}{l}\text { Social media } \\
\text { accounts }\end{array}$ & $\begin{array}{l}\text { Instant mes- } \\
\text { saging apps }\end{array}$ & Profession & Education \\
\hline Int1 & $18-25$ & $\mathrm{M}$ & 3 & 2 & Student & Bachelor's degree \\
\hline Int 2 & & $\mathrm{~F}$ & 3 & 2 & Student & Bachelor's degree \\
\hline Int 3 & & M & 2 & 3 & Professional & CMI level 7 \\
\hline Int 4 & & M & 2 & 1 & Business owner & GCSE \\
\hline Int 5 & & $\mathrm{~F}$ & 2 & 3 & Professional female & ACCA \\
\hline Int 6 & & M & 1 & 3 & Office worker & Bachelor's degree \\
\hline Int 7 & & $\mathrm{~F}$ & 3 & 2 & Housewife & Bachelor's degree \\
\hline Int 8 & & M & 5 & 3 & Student & Bachelor's degree \\
\hline Int 9 & $26-35$ & M & 1 & 3 & Professional worker & Master's degree \\
\hline Int 10 & & $\mathrm{~F}$ & 2 & 2 & Student & Bachelor's degree \\
\hline Int 11 & & M & 4 & 3 & Marketing consultant & Master's degree \\
\hline Int 12 & & $\mathrm{~F}$ & 1 & 4 & Housewife & Bachelor's degree \\
\hline Int 13 & & M & 2 & 4 & Student & $\mathrm{PhD}$ (continue) \\
\hline Int 14 & & $\mathrm{~F}$ & 2 & 3 & Mom & Bachelor's degree \\
\hline Int 15 & & $\mathrm{~F}$ & 2 & 2 & Housewife & Master's degree \\
\hline Int 16 & & M & 3 & 1 & Business owner & Master's degree \\
\hline Int 17 & & $\mathrm{~F}$ & 2 & 1 & Student & Bachelor's degree \\
\hline Int 18 & & M & 1 & 1 & Marketing consultant & Master's degree \\
\hline Int 19 & & $\mathrm{~F}$ & 1 & 2 & Professional lady & Master's degree \\
\hline Int 20 & & $\mathrm{~F}$ & 1 & 3 & Business owner & Master's degree \\
\hline Int 21 & & M & 1 & 2 & Business consultant & Master's degree \\
\hline Int 22 & & $\mathrm{M}$ & 2 & 1 & Office worker & Master's degree \\
\hline Int 23 & & $\mathrm{~F}$ & 2 & 3 & Housewife & Master's degree \\
\hline Int 24 & & $\mathrm{~F}$ & 3 & 3 & Housewife & Bachelor's degree \\
\hline Int 25 & $36-45$ & $\mathrm{~F}$ & 3 & 2 & Mom & Bachelor's degree \\
\hline Int 26 & & $\mathrm{~F}$ & 3 & 1 & Marketing consultant & Master's degree \\
\hline Int 27 & & M & 1 & 2 & Housewife & Bachelor's degree \\
\hline Int 28 & & $\mathrm{M}$ & 1 & 3 & Marketing consultant & Master's degree \\
\hline Int 29 & & $\mathrm{M}$ & 1 & 4 & Business owner & Master's degree \\
\hline Int 30 & $46-55$ & M & 1 & 3 & Professional worker & Master's degree \\
\hline Int 31 & & $\mathrm{~F}$ & 3 & 3 & IT professional & Master's degree \\
\hline Int 32 & & M & 2 & 3 & Office worker & Master's degree \\
\hline
\end{tabular}

carefully preparing interview transcripts, the researcher maintained them in an anonymous format as required by research ethics. In order to carefully code and organize the transcripts, the researcher used NVivo (Version 12); this would also facilitate data analysis. Saldana (2011) recommended researchers apply two coding cycles so that the quality of the research data can be ensured. The first cycle was descriptive coding, which involves coding a whole page or entire paragraph with just one letter. The second cycle was holistic, wherein coding portions were either reconfigured on the basis of the coding scheme or remained the same as a result of analytic memos. Rather than analyzing the entire data as a whole, holistic coding allows the inquirer to observe key themes within the data. As a result, the inquirer would be in a position to examine the relationship among various themes on social media and SCFBE. Finally, the emerged themes were authenticated through interpretation of key words and codes using a relativist and social constructionist perspective. The researcher rigorously followed the whole process to maintain rigor and transparency of this research. The researcher maintained the authenticity of this research by preparing and maintaining an audit trail in which the researcher documented the final and emergent themes. This would also enable the researcher to assert the transparency of this research. Figure 3 illustrates the thematic analysis model development process. Figure 4 presents an overview of sub-codes, codes, and themes used to develop the SCFBE model. 


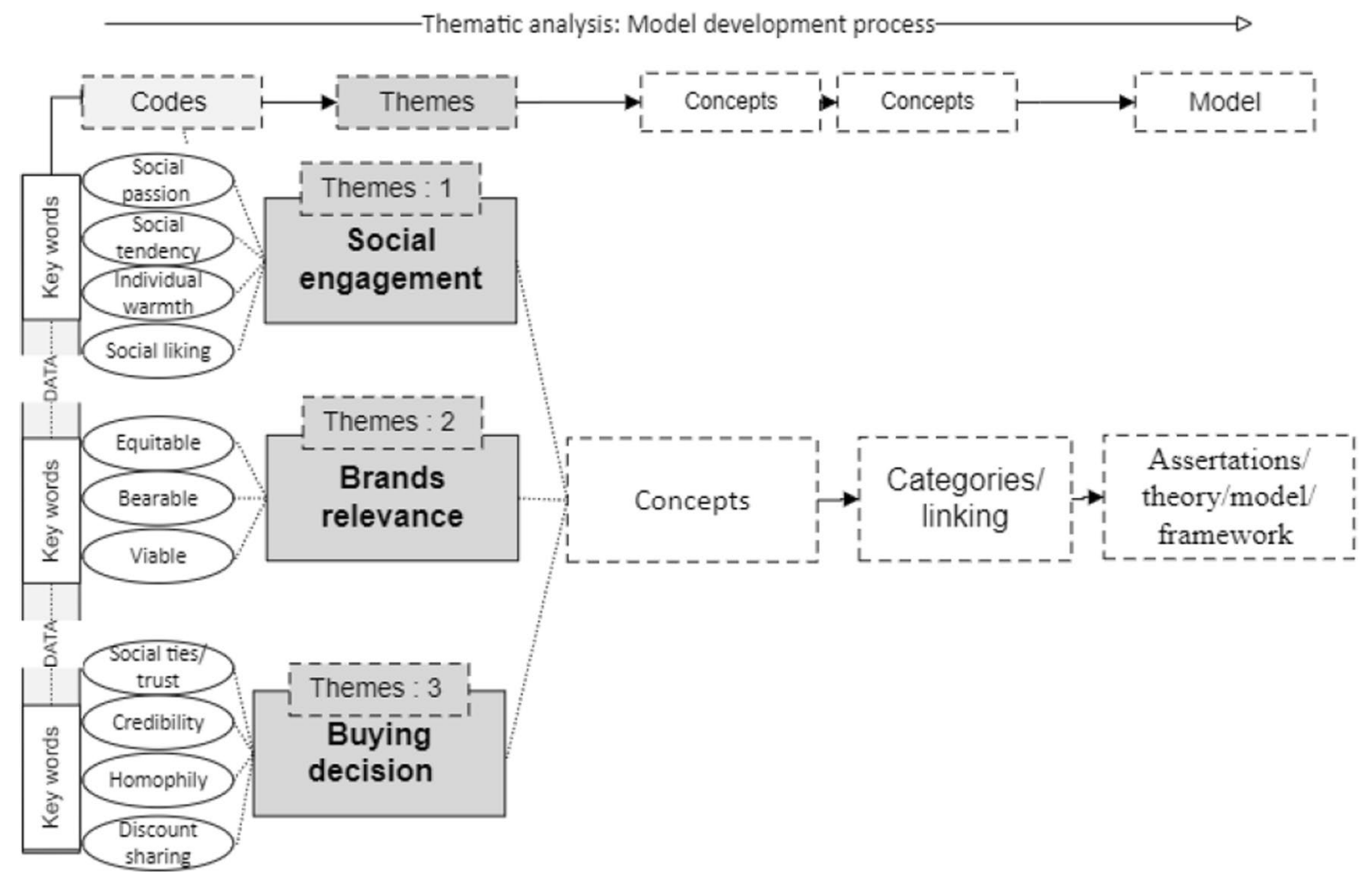

Fig. 3 Thematic analysis model development process

\section{Findings and analysis}

\section{Main theme 1: Social engagement}

\section{Code 1: Social passion}

Social passion refers to those social actors and personalities who can enhance social motivation, engagement, and following of specific fashion brands. Social media users believe that people with social passion know more about social trends, style, design, and other experiences. People are now more engaged with fashion experts and celebrities so that they may know what is on trend, and what fashion experts and celebrities are wearing in their daily lives. For example, Interviewee 2 said, "I really like Nike because many of my ideal and favourite celebrities wear it in their casual lives; so, their wearing and sharing on their Instagram creates my intention and I love this brand." It was found that positive reviews from opinion leaders can enhance attraction and engagement. For example, Interviewee 8 said, "I found positive reviews about Adidas whenever I asked those who have better knowledge and industry experience on Instagram, so this brand became attractive for me." People are now more engaged through Facebook and WhatsApp groups. These SMPs provide features that can connect people who have common interests, such as a desire to know more about their dream fashion brands. For example, Interviewee 1 said, "I follow some fashion group pages on Facebook where some known fashion experts share their views about Gucci and Tommy, so it catches my attention as I really like the designs and comfort in wearing." These groups have experts who are active and share their pictures and views about brands, which can enhance other social media users' interest.

\section{Code 2: Social tendency}

Social tendency refers to a socially generated inclination toward some specific fashion brands. Social tendency is generated by either crowd dynamics or fashion experts based on their valuable experiences and expertise in fashions brands. People follow fashion experts or crowd who have more knowledge and expertise, which can catch their attention and engagement via SMPs. For example, Interviewee 24 said, "I am very curious to buy new fashion so I can look different at parties and other social events. I found that many of my friends are more positive toward the new trends of Nike, so I am also inclined toward this brand." Sharing connections with friends can help people to know the latest fashion wave, which can enhance their level of social fashion brand engagement. For example, Interviewee 33 said, "I really like to keep myself within the fashion wave; therefore, most of my friends are fashion experts who keep sharing new fashion waves and trends, which really attracts me." People have a social circle, such as fashion experts, who 


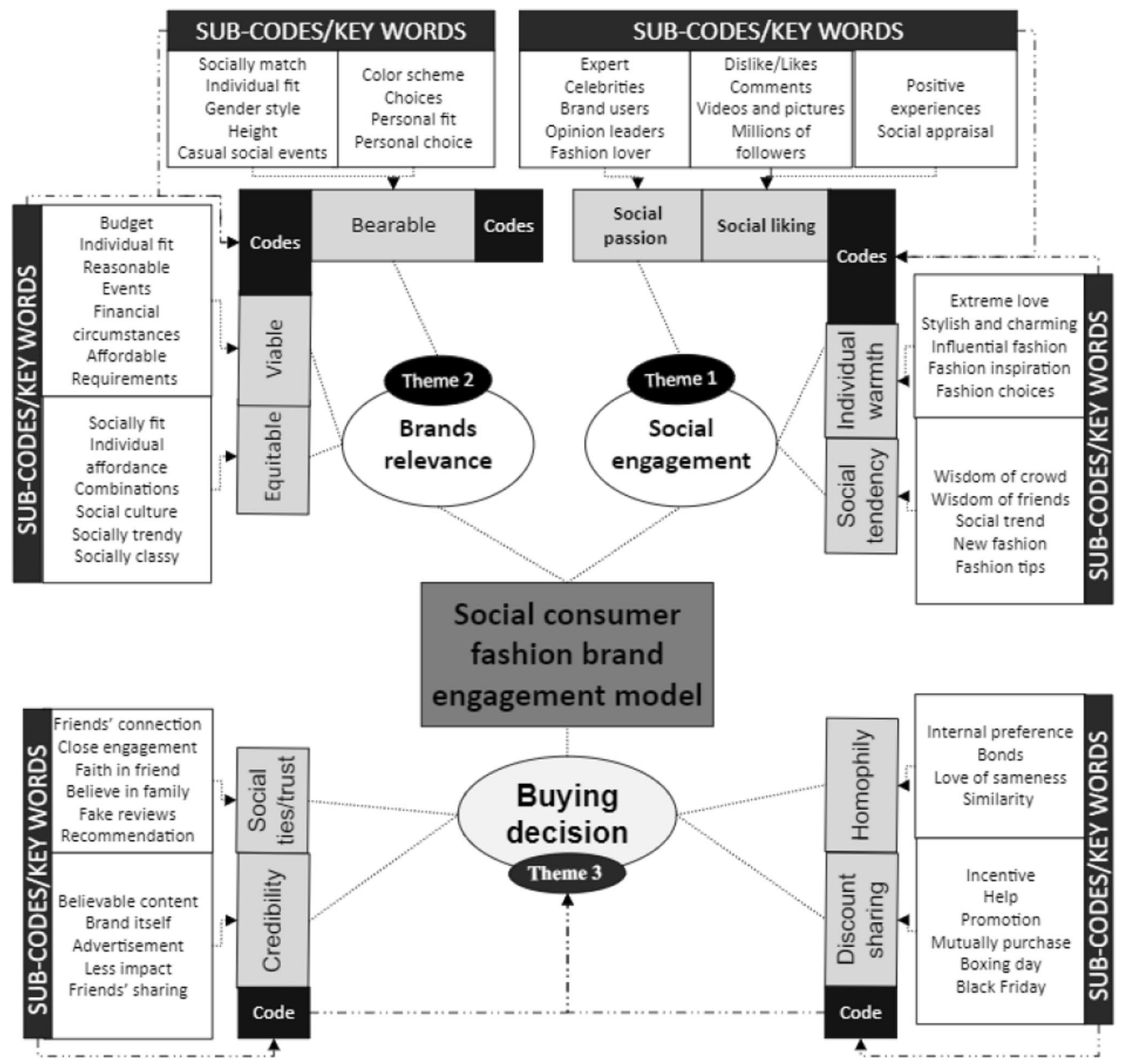

Fig. 4 Sub-codes, codes, and themes

have rich information regarding which brands are introducing socially stylish, trendy, classy fashion. Their attachment can enhance the credibility of the information. For example, Interviewee 17 said, "most of my friends who are fashion experts like North Face and Gucci because they are stylish, trendy, classy; so, I love these brands for me and my family."

\section{Code 3: Individual warmth}

Individual warmth refers to some individuals who are passionate about fashion and are influenced by others. In this category, some people are fashion trend setters, and some people are fashion trend followers. Some people have fashion expertise; their social circle take and encourage their recommendations. For example, Interviewee 18 said, "I have a huge following among friends and other social circles because of my fashion expertise, they really love my shared fashion; therefore, they keep appreciating and encouraging my sharing. They take me as a fashion inspiration; therefore, they want to follow so they can look like me." On the other hand, some people love to follow the fashion pages of SMPs with the purpose of knowing style trends and influential fashion. They love to follow people and pages of fashion because they are passionate to know what other people 
are wearing and what is suitable for their personalities. For example, Interviewee 38 said, "I like a page on Facebook where I found most influential fashion and style trends which catch my attention; therefore, I love to know more by reading the comments and experiences of others." Fashion trend followers follow personalities who are involved in new fashion waves and idea sharing on Instagram, Facebook, and Snapchat pages. For example, Interviewee 13 said, "I love to engage with friends and celebrities who have extreme love of Gucci and Tommy, which are my dream brands. I get many new ideas about fashion waves because they love to share their pictures on Instagram where they look super stylish and charming; so, I follow them due to their trendy choices."

\section{Code 4: Social liking}

Social liking of wisdom of friends, wisdom of crowd, opinion leaders, celebrities, and social passion can enhance social fashion brand engagement. Social liking is related to sources and the strength of people's views, which can influence their level of engagement with a brand. For example, Interviewee 27 said, "my favourite brands have been endorsed by a few personalities who are controversial; many of us and other social media users disliked our brands selecting such people as brand endorsers." People like to see that their brands are endorsed by credible people. It was also found that people like to associate with a social circle of equal social status and social liking toward a fashion brand. For example, Interviewee 5 said, "I have a social circle of friends who have high social status so I really liked their shared videos and pictures which increase my attachment to Gucci; so, I am also more attached now.” People share dislikes, likes, comments, pictures, videos, following, social appraisal, and experiences on SMPs to show their social liking of specific people who use their dream fashion brands. For example, Interviewee 10 said, "we follow a common childhood friend who has become a social celebrity and has millions of followers. We found a huge number of reasons and experiences about why my friend and their followers love Nike, so we really like this brand." People love to follow some professionals who are known as best recommenders for new trends and fashion style. These people are socially liked in their social circle because of their fashion brand choices.

\section{Main theme 2: Fashion brands relevance}

\section{Code 1: Equitable}

In the previous theme, we discussed the social actors and influencing factors that can enhance social fashion brand engagement. However, it is not enough that some people are socially engaged, fashion brands have to fit them socially and economically. Equitable means a remedy or solution that is a social economic fit under the circumstances, but may or may not be wholly satisfactory to any or all of the involved parties. Some people buy combinations of different brands because they are a social economic fit. For example, Interviewee 23 said, "although I and people close to me really like to wear Nike, this brand is not affordable. So, I buy the trendy cap of Nike but the trousers and shirt of another brand, so these combinations are a fit for me." Many interviewees acknowledged the social presence of some brands, but they believed that only a few brands, such as Nike, could fulfil their individual needs. For example, Interviewee 16 said, "as a housewife, I buy trendy and classy casual Nike clothes that align with social culture and are helpful during taking care of children." Another interviewee, Interviewee 40, said, "many of my friends wear Gucci products in casual social gatherings, but I and my family really do not like the collection. I love to wear Nike which is more related to our social and economic needs."

\section{Code 2: Bearability}

Bearability refers to those brands which have brand relevance as per social and individual fit. In more detail, we can explain bearability as something that a social media user can live with because of its individual fit, such as height, personality, color scheme, and personal liking. For example, Interviewee 31 said, "Although I really like the long coat of Nike, I am not very tall, which is why a long coat is not a social and individual fit for me. So, I choose only those Nike coats that are shared by my friends and that match my personality and social need." Similarly, Interviewee 11 said, "I desire to wear long shoes of North Face along with jeans to casual events, but I felt that my height is not very tall; so I am afraid that people may create jokes and fun about my choice. So, I selected only normal and casual shoes of North Face, which I found in a fashion group on Facebook." Some of the respondents stated that although Gucci products have social presence, Gucci colors are shiny; therefore, they and their family did not like the brand. For example, Interviewee 35 said, "I and my family don't really like the color scheme of Gucci because it is more shiny, but when my friends shared colors of North Face we were happier as these colors are liked by me and my family."

\section{Code 3: Viable}

Viable refers to the extent to which a brand meets economic and individual needs. More specifically, viability is the suitability of a fashion brand for what it is intended to do within economic and individual context, such as clothes for special events and requirements of homemakers, students, or professionals. Although some people passionately want to buy brand products, they cannot afford most of these products; as 
a result, they wait for special sales days. For example, Interviewee 14 said, "I am really passionate about and love to wear Nike but, unfortunately, it does not fit my budget, that's why I wait for some special days on which I can afford some items which fit my personal needs." Some people said that wearing brands at special events matched their economic and individual needs. For example, Interviewee 18 said, "I think a tuxedo shirt and bowtie of North Face for a wedding event and these items are a fit and affordable for me." A student highlighted that Adidas shirt, footwear, and trousers are not an economic fit for his sports activities, even though he really likes them; so, special sales days provide an opportunity to search for items of his desired brand that are at a reasonable price for him. For example, Interviewee 37 said, "As a student, Adidas footwear, shirt, and trousers for cricket are not affordable, that is why I wait for special sales days which can provide me with an opportunity to search for anything that is reasonable for me."

\section{Main theme 3: Fashion brands buying decision}

\section{Code 1: Social ties and trust}

Social ties refers to the extent to which people are connected and engaged. Social trust is defined here as the social morality as well as the social honesty of a source to create recommendations that help their close social circle in their fashion brand buying. It was found that some social media users are happy to trust social connections who are known to them, such as true friends and family members; these trusted connections share information that helps buying decisions. For example, Interviewee 24 said, "I have faith in my close friends who are true to me because they often recommend products of Nike and Adidas through Facebook Messenger or WhatsApp, which are right for buying as per their experiences and expertise. I really do not believe celebrities and other people, so I am connected with my close friends and ask for their views for right buying." Some interviewees reported that their close sources told them that fake reviews are common for good and average brands; therefore, they only believe in the recommendations of true friends and family members who are faithful and close. For example, Interviewee 1 said, "many of my friends and experts who are connected with me, told how the creation of fake reviews for good and average brands is a common strategy. So now I only believe in some true friends and family members who know more about my dream brands like Adidas and Tommy, so I often buy on their recommendations only."

\section{Code 2: Credibility}

Credibility refers to content that is trustable and believable, which can help social media users in their buying of fashion brands. Although there are many social actors, such as celebrities, consumers, opinion leaders, experts, friends, and family members, who are engaged and involved in content generation related to brands, only the content from specific users has an impact on social media users' purchase decisions for fashion brands. The credibility of content from a source can be based on the source's personal knowledge and expertise as well as on their social connection to a target. For example, people take recommendations from close friends because they are known, trustable, and share information which favors their social circle. For example, Interviewee 11 said, "I personally believe that an advertisement of a brand is created by the brand for itself, so it has less impact on me and people. These advertisements are good sources of information especially for Tommy and Gucci, which I like most. However, the experiences of my friends are more believable for buying and they often share on social media instant messaging apps." Trustworthy relations, strong social ties, and legitimate content are major factors for buying decisions. For example, Interviewee 3 said, "I believe that fashion brand content shared by my close friends and family has more weight and legitimacy for me; so, I often take their suggestions and they always help me a lot in buying decision of Gucci and Tommy in which a lot of money is involved."

\section{Code 3: Homophily}

Homophily is when people who have the same preference, close bonds, liking for the same thing, or similar views and needs may accept each other's views because they are helpful for buying. Social media develops and strengthens group networking; people may buy the same brands as their friends because they want to wear commonly liked brands. For example, Interviewee 11 said, "I follow my student friends because some of them are experts in fashion, so they always share those products of Nike and Adidas which are fit and trendy for our group. Sometimes we buy one type of product together because we are a one group identity and we have a love of sameness." It was found that some parents who were physically known to each other created a group on WhatsApp where they shared information about clothing, especially for their children. For example, Interviewee 16 said, "we have a group of friends on WhatsApp who are moms and know each other's clothing needs at a personal and family level. I often found they share relevant clothing and footwear of Nike and North Face, which usually match the needs of my children. So, many times, I buy right products of our favourite brands because of social network."

\section{Code 4: Discount sharing}

The sharing of discounted offers (i.e., incentives, special days offers, rebates, and coupons) through social media 
networking can motivate an individual to buy even if they do not have prior intention to buy. Some people stated that their social circle, such as friends, are aware of their liking for Nike and Adidas products; therefore, their friends often share information on discounted and affordable products of these brands. For example, Interviewee 13 said, "I love to search discounted or any incentive for Nike and Adidas brands and my friends really helped me as they shared many times products of my favourite brands which are on discount sale and affordable for me, so I bought these brands many times." Other people stated that social media helped them to engage with their social circle; therefore, they were more aware about coupons, rebates, promotional schemes, and discounted deals. However, sometimes, although they had no prior intention to buy, the sharing of discounted deals created that intention. For example, Interviewee 30 said, " $m y$ social circle really like to share many discount offers, such as coupons, rebates, and promotional schemes of my favourite brands (i.e., Nike and Gucci); so, sometimes, I bought these discounted items even when I had no prior intention to buy them."

\section{Discussion and conclusions}

The first objective of this study was to understand social factors that can enhance social brand fashion engagement on SMPs. Previous studies have highlighted that social brand engagement can be enhanced through social media and that social media also enhanced the intention to use brands (Osei-Frimpong and McLean 2018; Osei-Frimpong et al. 2019). However, these studies did not specify the social actors and other factors that can enhance social engagement with brands. The results of this study reveal that people who are socially engaged do not necessarily buy brands, and they highlighted that specific social factors can convert social brand engagement into consumer brand engagement. The first factor that can enhance social fashion brand engagement is socially generated passion through SMPs. Mukherjee (2020) argued that passion can be described as extreme positive feelings that can develop into a relationship between a consumer and a brand. This study described social passion as social media actors who can enhance social motivation and engagement with specific brands. These social actors are brand experts, celebrities, brand users, and opinion leaders who have a high level of information about social trends, fashion waves, style, design, and other experiences that can influence their followers and foster the development of a positive relationship with fashion brands.

Passion is the driving force behind the motivation to engage in a social activity. Laroche et al. (2012) and Kozinets (2014) defined social engagement as creation, connection, and communication of the brand's story between consumers and firm utilizing brand-related images, language, and meanings through a social networking site. The results reveal that people are socially engaged with celebrities and fashion experts through Instagram, so when they share pictures, posts, and videos on their Instagram pages, it enhances the level of brand-related information. This socially shared information can enhance brand passion and social engagement with fashion brands. Previous studies also reported that celebrities' attractiveness and endorsement can enhance their followers' love for specific brands (Carroll 2009; Felix and Borges 2014). This study found that social media users believe celebrities and fashion experts can provide information about social trends of fashion and attractive styles that can enhance social passion toward fashion brands; however, they do not necessarily create buying intentions because social media users perceive that celebrities and fashion experts may be paid influencers. Opinion leaders' and brand users' reviews are active on fashion pages of Facebook where they enhance word of mouth, connections, and impact for fashion brands.

Social tendency is another factor that can enhance social fashion brand engagement through SMPs. A previous study described social tendency as socially constructed which helps to incline users toward a specific reality (Lindsey and Greene 1987). This study constructs the meanings of social tendency specifically in the context of social fashion brand engagement. Social tendency refers to a socially generated inclination toward some specific fashion brands. Two factors can enhance a social media user's inclination toward fashion brands: wisdom of crowd and wisdom of fashion experts. The wisdom of fashion experts refers to those people who have high awareness about socially stylish, trendy, classy fashion; therefore, they are major influencers for their social circle and their recommendations can enhance their social circle's inclination toward fashion brands. Some people joined fashion pages where people share their experiences as brand users and these experiences can enhance other social media users' engagement with fashion brands. Individual warmth is another factor that can enhance passion. It was found that some people are fashion trend setters and some people are fashion trend followers. People who have fashion expertise may act as a social influencer for their social circle. People's likes, tweets, sharing, and posting of pictures, video, and audios on social media can enhance social liking of fashion brands. Recent studies also highlighted that social media interactions can enhance positive intentions for buying brands (Algharabat et al. 2020; Cheung et al. 2020).

The second objective of this study was to find the elements of fashion brand relevance. Although brand relevance was explored in the context of viral advertisements and competitors (Aaker 2010, 2012; Huang and Zhou 2016), these studies did not discuss the specific elements that can enhance fashion brand relevance among social media users. There 
are three elements of fashion brand relevance: equitable, bearability, and viable (see Fig. 5). The conceptualization of these factors is a unique contribution of this study. For example, the first element of brand relevance is equitable, which means either a remedy or solution that is a social economic fit under the circumstances, but it may or may not be wholly satisfactory to any or all of the involved parties (see Fig. 4). Nike has high social presence and people want to get Nike products for social impact, but they might not be an economic fit; therefore, some interviewees felt that a combination of different brands was more relevant economically.

The second element of brand relevance is bearability, which means a social media user can live with a fashion brand because of its personal fit, such as height, personality, color match, and personal liking. The third element of brand relevance is viable, which means suitability of a fashion brand for what it is intended to do within the economic and individual context (see Fig. 4); for example, clothes for special events or purchasing expensive brand items on sales days.

The third and major objective of this study was to find the drivers of buying decisions for fashion brands, which reflected the major difference between social fashion brand engagement and consumer fashion brand engagement. Consumer fashion brand engagement refers to the social actors and influencing factors that can develop an intention to buy specific brands. Consumer fashion brand engagement includes the factor of compliance in which social media users accept the opinions of people close to them because they believe that their recommendations and experiences can

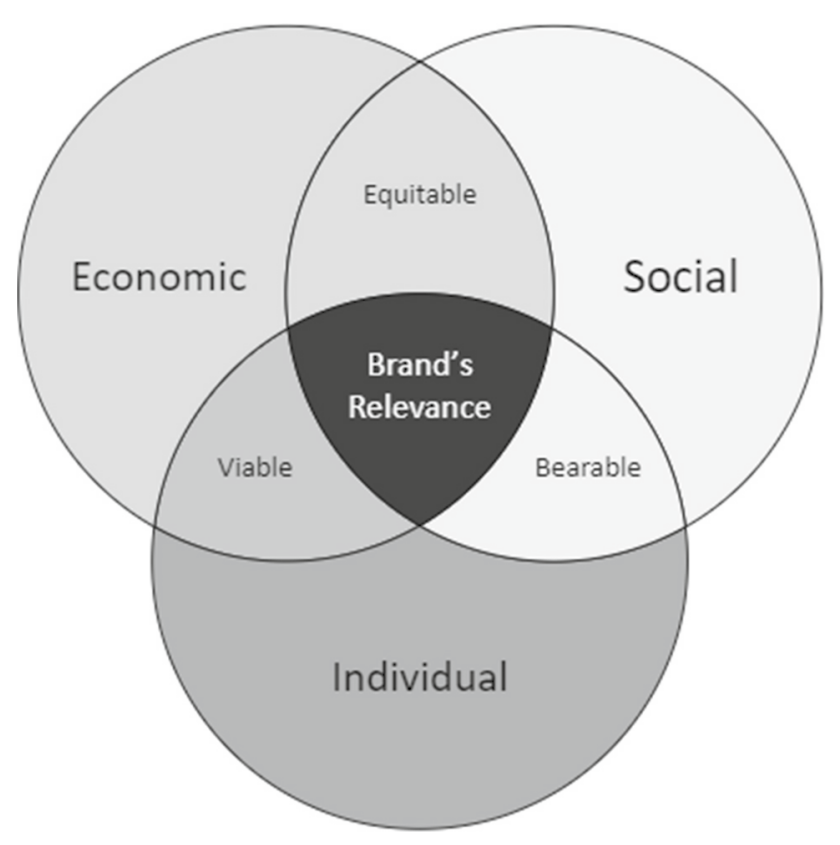

Fig. 5 Fashion brand relevance create favorable outcomes. Close people could be fashion experts' friends or other friends who have information and experiences of brands. Previous studies have focused on the link between discounts and people's intention to buy brands (Chowdhury and Akter 2018; Kim and Lee 2020; Dahana et al. 2019), but this study explored social ties and trust, credibility, and homophily as major factors that can impact the buying intentions of social media users.

Social ties refers to people's connections and the network used to share knowledge with others and these connections can be either strong or weak (Shriver et al. 2013; Mattie et al. 2018); only strong connections influence buying intentions for fashion brands. The present study explored which close social ties/actors create buying intentions toward specific fashion brands. It was found that social media instant messaging apps, such as WhatsApp and Messenger, provided interviewees with an opportunity to engage with their strong social ties who are known and trusted. People stated that some of their friends had experiences and expertise that helped them when they bought expensive brands like Nike and Adidas. Ayeh et al. (2013) observed that credibility is fast becoming a relevant factor because of the increasing amount of content on social media. Furthermore, Chen et al. (2011) observed that the credibility of information is of high importance with respect to its influence on people. This study found that interviewees were aware of fake reviews and that brands have invested money in celebrities. Interviewees regarded content generated by friends and family as more credible than content generated by other social media users.

\section{Contribution}

This study has made three contributions. First, this study found that social passion, social tendency, individual warmth, and social liking are factors that can enhance fashion brand engagement. The results of this study are partially supported by Sternberg's triangular theory of love. Sternberg's triangular theory of love highlighted that an interpersonal relationship or love is established on the basis of three components: passion, intimacy, and decision/commitment (Sternberg 1986); these components can enhance relationships with brands (Albert et al. 2013). This study conceptualized social passion as social media actors who enhance social motivation, engagement, and following of brands. Sternberg (1986) explained intimacy as closeness or attractiveness toward specific things. Social tendency refers to the inclination to purchase specific fashion brands generated from the wisdom of fashion experts or the wisdom of the crowd. Results revealed that fashion experts recommendations can generate social tendency toward fashion brands (see Fig. 6). 


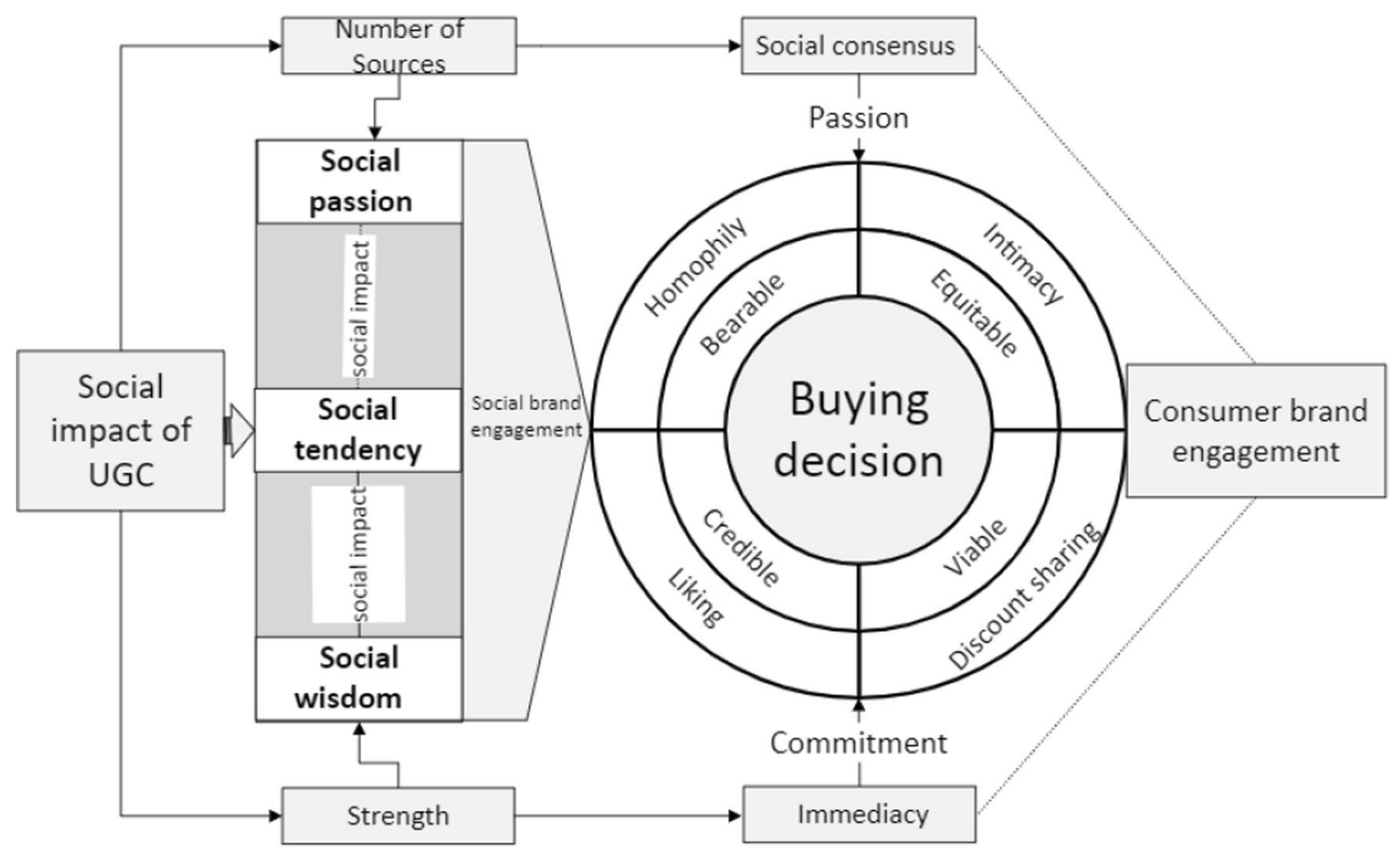

Fig. 6 Social consumer fashion brand engagement model

The second major contribution of this study is to offer three elements of fashion brand relevance: equitable, bearability, and viable. Equitable refers to whether a consumer's selection of a fashion brand is a social economic fit. Bearability refers to a consumer's selection of fashion brands with respect to social and individual fit. Viable is suitability of a fashion brand for what it is intended to do within the economic and individual context, such as clothes for special events.

The third major contribution is the SCFBE model, which describes how people are socially engaged with fashion brands through SMPs. This model enables conceptualization of fashion brand relevance for social media users and the specific drivers that can lead to buying decisions. The results of this study are supported by social impact theory, which describes the impact of strength and immediacy on buying decisions. For example, this study has found that a strong source (e.g., wisdom of friends) can engage many close friends, who share useful information about commonly liked brands. The second important factor of social impact theory is immediacy (i.e., the shorter the physical distance, the greater the impact). The results of this study revealed that the use of SMPs provided opportunities to social media users to fully engage with those who shared their interests, whose recommendations have a high impact because of their proximity (see Fig. 6). Based on this theoretical contribution, nine propositions are developed that are given below:
P1: Social media actors (i.e., celebrities, opinion leaders, fashion experts, crowd and brands users) can enhance social motivation and social media engagement with fashion brands.

P2: The social 'liking' (i.e., social networking appraisal, likes, dislikes, and sharing of audio, videos, and pictures) can increase the level of social fashion brand engagement.

P3: The socially generated tendency can be enhanced through the wisdom of crowds in relation to specific fashion brands.

P4: The individual warmth (i.e., fashion trendsetters and fashion trend followers) can increase passion or social brand engagement.

P5: A combination of different brands complementing social economic fit (equitable fit) can enhance intentions to purchase.

P6: Socially accepted personal fit (bearability) can enhance intentions to purchase.

P7: An individual economic fit (viability) can enhance the intentions to purchase.

P8: The recommendations and experiences of friends and family members can enhance purchasing decisions for fashion brands.

P9: The high socialization can enhance social brand engagement, whereas rewards and benefits can enhance consumer brand engagement. 


\section{Limitations and future directions}

The study collected data from UK-based consumers of fashion brands, but the use of SMPs, influencers, social actors' impact, elements of brand relevance, and drivers of buying decisions can vary between different cultures, consumers, and brands.

The validity and reliability of the SCFBE model can be enhanced if future studies test the model using rigorous statistical analysis.

Future studies can draw a comparison between luxurious and non-luxurious fashion brands to further understanding of SCFBE.

\section{Declarations}

Conflict of interest On behalf of all authors, the corresponding author states that there is no conflict of interest.

\section{References}

Aaker, D.A. 2010. Brand relevance: Making competitors irrelevant. New York: Wiley.

Aaker, D.A. 2012. Win the brand relevance battle and then build competitor barriers. California Management Review 54(2): 43-57.

Albert, N., D. Merunka, and P. Valette-Florence. 2008. When consumers love their brands: Exploring the concept and its dimensions. Journal of Business Research 61(10): 1062-1075.

Albert, N., D. Merunka, and P. Valette-Florence. 2013. Brand passion: Antecedents and consequences. Journal of Business Research 66(7): 904-909.

Algharabat, R., N.P. Rana, A.A. Alalwan, A. Baabdullah, and A. Gupta. 2020. Investigating the antecedents of customer brand engagement and consumer-based brand equity in social media. Journal of Retailing and Consumer Services. https://doi.org/10.1016/j.jretc onser.2019.01.016.

Ananda, A.S., Á. Hernández-García, E. Acquila-Natale, and L. Lamberti. 2019. What makes fashion consumers "click"? Generation of eWoM engagement in social media. Asia Pacific Journal of Marketing and Logistics 31(2): 398-418. https://doi.org/10.1108/ APJML-03-2018-0115.

Arnold, A. 2017. Ways Social Media Influences Millennials' Purchasing Decisions. Available at: https://www.forbes.com/sites/andre warnold/2017/12/22/4-ways-social-media-influences-millennialspurchasing-decisions/\#7de987b2539f

Aslam, U., F. Muqadas, M.K. Imran, and U.-U. Rahman. 2018. Exploring the sources and role of knowledge sharing to overcome the challenges of organizational change implementation. International Journal of Organizational Analysis 26(3): 567-581.

Astakhova, M., K.R. Swimberghe, and B.R. Wooldridge. 2017. Actual and ideal-self congruence and dual brand passion. Journal of Consumer Marketing 34(7): 664-672. https://doi.org/10.1108/ JCM-10-2016-1985.

Auerbach, C., and L.B. Silverstein. 2003. Qualitative data: An introduction to coding and analysis, vol. 21. NYU press.

Balakrishnan, J., and M.D. Griffiths. 2017. Social media addiction: What is the role of content in YouTube? Journal of Behavioral
Addictions 6(3): 364-377. https://doi.org/10.1556/2006.6.2017. 058.

Bitsch, V. 2005. Qualitative research: A grounded theory example and evaluation criteria. Journal of Agribusiness 23: 75-91.

Buschgens, M., B. Figueiredo, and K. Rahman. 2020. How brand owners construct imagined worlds with brand visual aesthetics. Journal of Brand Management 27(3): 266-283.

Byrum, K. 2019. "Hey friend, buy green": Social media use to influence eco-purchasing involvement. Environmental Communication 13(2): 209-221. https://doi.org/10.1080/17524032.2017. 1308404.

Carroll, A. 2009. Brand communications in fashion categories using celebrity endorsement. Journal of Brand Management 17(2): 146-158. https://doi.org/10.1057/bm.2008.42.

Chen, Y., S. Fay, and Q. Wang. 2011. The role of marketing in social media: How online consumer reviews evolve. Journal of interactive marketing 25(2): 85-94.

Cheung, M.L., G. Pires, and P.J. Rosenberger. 2020. The influence of perceived social media marketing elements on consumer-brand engagement and brand knowledge. Asia Pacific Journal of Marketing and Logistics 32(3): 695-720.

Chowdhury, T.A., and T. Akter. 2018. "Fashion attributes preferred by young Bangladeshi consumers while buying casual clothes: A multi-dimensional approach. Journal of Fashion Marketing and Management 22(4): 540-556. https://doi.org/10.1108/ JFMM-02-2018-0018.

Dahana, W.D., Y. Miwa, and M. Morisada. 2019. Linking lifestyle to customer lifetime value: An exploratory study in an online fashion retail market. Journal of Business Research 99: 319-331.

Felix, R., and A. Borges. 2014. Celebrity endorser attractiveness, visual attention, and implications for ad attitudes and brand evaluations: A replication and extension. Journal of Brand Management 21(78): 579-593.

Godey, B., A. Manthiou, D. Pederzoli, J. Rokka, G. Aiello, R. Donvito, and R. Singh. 2016. Social media marketing efforts of luxury brands: Influence on brand equity and consumer behavior. Journal of Business Research 69(12): 5833-5841.

Helme-Guizon, A., and F. Magnoni. 2019. Consumer brand engagement ad its social side on brand-hosted social media: how do they contribute to brand loyalty? Journal of Marketing Management 35(7-8): 716-741.

Hollebeek, L.D., M.S. Glynn, and R.J. Brodie. 2014. Consumer brand engagement in social media: Conceptualization, scale development and validation. Journal of Interactive Marketing 28(2): 149-165.

Huang, J.S., and L. Zhou. 2016. Negative effects of brand familiarity and brand relevance on effectiveness of viral advertisements. Social Behavior and Personality: an International Journal 44(7): 1151-1162.

Jin, S.V., and E. Ryu. 2019. Celebrity fashion brand endorsement in Facebook viral marketing and social commerce: Interactive effects of social identification, materialism, fashion involvement, and opinion leadership. Journal of Fashion Marketing and Management 23(1): 104-123. https://doi.org/10.1108/ JFMM-01-2018-0001.

Kim, Y., and Y. Lee. 2020. Cross-channel spillover effect of price promotion in fashion. International Journal of Retail \& Distribution Management. https://doi.org/10.1108/IJRDM-12-2019-0393.

Kizgin, H., A. Jamal, B.L. Dey, and N.P. Rana. 2018. The impact of social media on consumers' acculturation and purchase intentions. Information Systems Frontiers 20(3): 503-514. https://doi.org/10. 1007/s10796-017-9817-4.

Kozinets, R.V. 2014. Social brand engagement: A new idea. NIM Marketing Intelligence Review 6(2): 8-15.

Laroche, M., M.R. Habibi, M.O. Richard, and R. Sankaranarayanan. 2012. The effects of social media based brand communities 
on brand community markers, value creation practices, brand trust and brand loyalty. Computers in Human Behavior 28(5): $1755-1767$.

Latané, B. 1981. The psychology of social impact. American Psychologist 36(4): 343-356.

Latané, B. 1996. Dynamic social impact: The creation of culture by communication. Journal of Communication 46(4): 13-25.

Latane, B., and S. Wolf. 1981. The social impact of majorities and minorities. Psychological Review 88: 438-453.

Lee, J.E., S. Hur, and B. Watkins. 2018. Visual communication of luxury fashion brands on social media: Effects of visual complexity and brand familiarity. Journal of Brand Management 25(5): 449-462.

Lincoln, Y.S., and E.G. Guba. 1982. Establishing dependability and confirmability in naturalistic inquiry through an audit.

Lindsey, A.E., and J.O. Greene. 1987. Social tendencies and social knowledge: Self-monitoring differences in the representation and recall of social knowledge. Communications Monographs 54(4): 381-395.

Loureiro, S.M.C., I. Costa, and P. Panchapakesan. 2017. A passion for fashion: the impact of social influence, vanity and exhibitionism on consumer behaviour. International Journal of Retail \& Distribution Management 45(5): 468-484.

Martínez-López, F.J., R. Anaya-Sánchez, M. Fernández Giordano, and D. Lopez-Lopez. 2020. Behind influencer marketing: key marketing decisions and their effects on followers' responses. Journal of Marketing Management 36(7-8): 579-607.

Mattie, H., K. Engø-Monsen, R. Ling, and J.P. Onnela. 2018. Understanding tie strength in social networks using a local "bow tie" framework. Scientific Reports 8(1): 1-9.

Mir, I., and A. Zaheer. 2012. Verification of social impact theory claims in social media context. Journal of Internet Banking and Commerce: $J I B C$ 17(1): 1.

Morra, M.C., V. Gelosa, F. Ceruti, and A. Mazzucchelli. 2018. Original or counterfeit luxury fashion brands? The effect of social media on purchase intention. Journal of Global Fashion Marketing 9(1): 24-39.

Mukherjee, K. 2020. Social media marketing and customers' passion for brands. Marketing Intelligence \& Planning 38(4): 509-522.

Muntinga, D.G., M. Moorman, and E.G. Smit. 2011. Introducing COBRAs: Exploring motivations for brand-related social media use. International Journal of Advertising 30(1): 13-46.

Naeem, M. 2020. Uncovering the role of social motivational factors as a tool for enhancing brand-related content. Qualitative Market Research 23(2): 287-307. https://doi.org/10.1108/ QMR-10-2019-0121.

Naeem, M., and W. Ozuem. 2020. Developing UGC social brand engagement model: Insights from diverse consumers. Journal of Consumer Behaviour. https://doi.org/10.1002/cb.1873.

Narangajavana Kaosiri, Y., L.J. Callarisa Fiol, M.Á. Moliner Tena, R.M. Rodríguez Artola, and J. Sánchez García. 2019. User-generated content sources in social media: A new approach to explore tourist satisfaction. Journal of Travel Research 58(2): 253-265. https://doi.org/10.1177/0047287517746014.

Osei-Frimpong, K., and G. McLean. 2018. Examining online social brand engagement: A social presence theory perspective. Technological Forecasting and Social Change 128: 10-21.

Osei-Frimpong, K., G. McLean, and S. Famiyeh. 2019. Social media brand engagement practices: Examining the role of consumer brand knowledge, social pressure, social relatedness, and brand trust. Information Technology \& People 33(4): 1235-1254. https:// doi.org/10.1108/ITP-05-2018-0220.

Park, M., H. Im, and H.Y. Kim. 2018. "You are too friendly!" The negative effects of social media marketing on value perceptions of luxury fashion brands. Journal of Business Research. https:// doi.org/10.1016/j.jbusres.2018.07.026.
Peters, K., Y. Chen, A.M. Kaplan, B. Ognibeni, and K. Pauwels. 2013. Social media metrics-A framework and guidelines for managing social media. Journal of Interactive Marketing 27(4): 281-298. https://doi.org/10.1016/j.intmar.2013.09.007.

Pourazad, N., L. Stocchi, and V. Pare. 2019. The power of brand passion in sports apparel brands. Journal of Product \& Brand Management. https://doi.org/10.1108/JPBM-12-2018-2164.

Ramirez, E., R. Gau, J. Hadjimarcou, and Z. Xu. 2018. User-generated content as word-of-mouth. Journal of Marketing Theory and Practice 26(1-2): 90-98.

RetailWire. 2019. Nearly half of online fashion shoppers say social media inspired their last purchase. Available at: https://retai lwire.com/discussion/nearly-half-of-online-fashion-shopperssay-social-media-inspired-their-last-purchase/. Accessed on Oct $18,2019 \mathrm{~s}$

Saldana, J. 2011. Fundamentals of qualitative research. OUP USA.

Saunders, B., J. Sim, T. Kingstone, S. Baker, J. Waterfield, B. Bartlam, H. Burroughs, and C. Jinks. 2018. Saturation in qualitative research: exploring its conceptualization and operationalization. Quality \& Quantity 52(4): 1893-1907.

Schivinski, B., and D. Dabrowski. 2016. The effect of social media communication on consumer perceptions of brands. Journal of Marketing Communications 22(2): 189-214.

Shriver, S.K., H.S. Nair, and R. Hofstetter. 2013. Social ties and user-generated content: Evidence from an online social network. Management Science 59(6): 1425-1443.

Simon, C., T.O. Brexendorf, and M. Fassnacht. 2016. The impact of external social and internal personal forces on consumers' brand community engagement on Facebook. Journal of Product \& Brand Management 25(5): 409-423. https://doi.org/10.1108/ JPBM-03-2015-0843.

Simon, F., and V. Tossan. 2018. Does brand-consumer social sharing matter? A relational framework of customer engagement to brand-hosted social media. Journal of Business Research 85: 175-184.

Slater, M.D. 2007. Reinforcing spirals: The mutual influence of media selectivity and media effects and their impact on individual behavior and social identity. Communication Theory 17(3): 281-303. https://doi.org/10.1111/j.1468-2885.2007.00296.

Sternberg, R.J. 1986. A triangular theory of love. Psychological Review 93(2): 119-135.

Swimberghe, K.R., M. Astakhova, and B.R. Wooldridge. 2014. A new dualistic approach to brand passion: harmonious and obsessive. Journal of Business Research 67(12): 2657-2665.

Tsai, W.H.S., and L.R. Men. 2013. Motivations and antecedents of consumer engagement with brand pages on social networking sites. Journal of Interactive Advertising 13(2): 76-87.

Publisher's Note Springer Nature remains neutral with regard to jurisdictional claims in published maps and institutional affiliations.

Muhammad Naeem is an enthusiastic professional with eight years' marketing consultancy experience. I have wealth of practical work experience as the former Managing Director of a marketing consultancy firm in Manchester, UK. Currently, I am acting as Managing Director of a training and development organization called Research Skills Academy Ltd. I have completed my DBA from university of Worcester, UK. Some of my papers are accepted for publication, and some are published in impact factor journals such as journal of consumer and retailing services, journal of consumer behavior an international journal, business process management journal, and Asian pacific journal of marketing and logistics. I am focused on how digital and social media have changed the nature of brand engagement and customer/consumer perspectives. 
Wilson Ozuem teaches and researches communication issues in computer-mediated marketing environments (CMMEs). The results of his research have been published in scholarly journals, books and international conference papers, including the European Journal of Marketing, Journal of Business Research, Psychology and Marketing, Information Technology and People, Journal of Strategic Marketing Journal of Retailing and Consumer Services. Dr. Ozuem was a former Senior Research Fellow (Digital Economy) at the University of Gloucestershire. Prof. Ozuem has successfully supervised $15 \mathrm{PhD} /$
DBA to completion. He was previously an associate professor in Digital Marketing at Regents University, London. He currently teaches and supervises both postgraduate and undergraduate students in several universities, including Warwick University (UK), City, University of London, University of Birmingham and Arden University. He has completed $\mathrm{PhD}$ in Digital Marketing from Anglia Ruskin University and Postgraduate Degree in Educational Research from the University of Cambridge. 